\title{
Genetic Variability, Heritability and Expected Genetic Advance as Indices for Selection in Soybean [Glycine max (L.) Merrill] Varieties
}

\author{
Besufikad Enideg Getnet \\ Department of Plant Science, Gambella University, Gambella, Ethiopia
}

Email address:

besuloza@gmail.com

\section{To cite this article:}

Besufikad Enideg Getnet. Genetic Variability, Heritability and Expected Genetic Advance as Indices for Selection in Soybean [Glycine max (L.) Merrill] Varieties. American Journal of Life Sciences. Vol. 6, No. 4, 2018, pp. 52-56. doi: 10.11648/j.ajls.20180604.11

Received: November 8D, 2018; Accepted: December 7, 2018; Published: January 4, 2019

\begin{abstract}
Genetic variability, heritability and genetic advance under selection studies were conducted at Assosa on 49 soybean genotypes. A field study laid out in 7x7 simple lattice design with two replications at Assosa Agricultural Research Center with the objective of estimating genetic variability, heritability, expected genetic advance, and to estimate genetic divergence, thereby, to cluster the test genotypes in to genetically divergent classes. The result of this study indicated variations for all the traits evaluated. The highest heritability value was recorded for days to $50 \%$ flowering followed by days to maturity and days to pod setting. Wide range of mean values was observed in all the characters evaluated. This indicates that the characters can be improved through selection. Divergence analysis grouped the 49 soybean genotypes into three. The principal component analysis revealed that five principal components PC1 to PC5 with Eigen values 4.27, 2.53, 1.91, 1.28 and 1.08 respectively, have accounted for $73.81 \%$ of the total variation.
\end{abstract}

Keywords: Divergence Analysis, Genetic Variability, Heritability, Principal Component Analysis

\section{Introduction}

Soybean Glycine $\max$ (L.) Merrill] is the world's leading source of oil and protein. It has the highest protein content $(40 \%)$ of all food crops and is second only to groundnut in terms of oil content $(20 \%)$ among food legumes. The meal is also rich in minerals, particularly calcium, phosphorus and iron $[3,4,10,11]$. The crop belongs to the family Leguminacae, subfamily Papilionoideae, tribe phaseolae, and genus Glycine. It is reported to be domesticated in Asia, probably in north eastern China about 2500 B.C. [1, 2, 7, 18].

Soybean breeding in Ethiopia was started in the 1950s on evaluation of introduced varieties with main emphasis of replacing soybean flour import with locally produced soybean flour and introducing the crop in to the existing crop production system and in the diet of the poor farmers $[4,8,9$, $11]$.

As soybean breeding in Ethiopia is concentrated on plant introductions, which are being used as the only source of new genes, the introductions were evaluated to identify varieties well adapted to the country, and at the same time to identify potential areas for producing the crop [3-6, 19, 19, 21].

The magnitude of genetic variability present in a population of any crop species is central to crop improvement which must be exploited by plant breeders for yield improvement. Because the crop is grown in diverse agro-ecological environments, variation in genetic constitution do exist among the various genotypes. This implies the potential for utilizing such variability in crop improvement programs [12-14, 17].

Therefore, research is undertaken with the objective of estimating the extent of phenotypic and genotypic variability, heritability and genetic advance expected under selection.

\section{Materials and Methods}

An investigation study was carried out at Assosa Agricultural Research Center. 49 soybean genotypes were evaluated for their genetic parameter performances. The materials were sown out to the field in simple lattice design with two replications on the main cropping season of 2015. 


\subsection{The Experimental Site}

Assosa Agricultural Research Center is located at latitude $10^{\circ} 03^{\prime} 12 " \mathrm{~N}$ and longtiude: $34^{0}, 59^{\prime} 48^{\prime} \mathrm{E}$ at elevation of 1950 m. a. s. 1 . in western part of Ethiopia, $656 \mathrm{~km}$ away from the capital Addis Ababa. And it is categorized under Hot to warm moist lowland plain, Tepid to cool humid, sub humid lowland plain, Tepid to cool sub humid mountain. The area receives mean annual rainfall of about $950 \mathrm{~mm}$. Maximum and minimum temperatures of the site are $34.4^{\circ} \mathrm{c}$ and $9^{\circ} \mathrm{c}$, respectively. The major soil type of the area is Nitosol with $\mathrm{pH}$ of 5.8 .

\subsection{Experimental Design and Management}

The experiment was laid out in a 7X7 simple lattice design with two replications. The plot size was three rows of $4 \mathrm{~m}$ length with $0.6 \mathrm{~m}$ row spacing i.e. $4 \mathrm{~m} \times 0.6 \mathrm{~m}=4.8 \mathrm{~m}^{2}$.

In order to facilitate the nitrogen fixation process of the roots, rhizobia bacteria (Rhizobium japonicum) were incorporated into the soil uniformly.

\subsection{Data Analyses}

The data were subjected to statistical analysis of variance as per the simple lattice design for each character by the GLM and ANOVA procedures of SAS version 9.2 [22]. Efficiency of the simple lattice design relative to RCBD was checked and in most of the traits studied the lattice design was found to be more efficient than that of the RCBD. Least Significant Difference (LSD) was used to separate the means.

\section{Results and Discussion}

\subsection{Mean, Range and Estimates of Genetic Parameters}

Range and mean values of the 15 characters studied are shown in Table 1. The 49 soybean genotypes showed wide range of variability for all characters; except pod length and root dry weight. The highest grain yield $(2134 \mathrm{~kg} / \mathrm{ha})$ was recorded from the genotype $T G X-1895-33 F$ and the lowest yield (444 kg/ha) was obtained from $G 00386$. The grand mean of grain yield was $885.76 \mathrm{~kg} / \mathrm{ha}$. Earlier days to flowering, days to pod setting and days to maturity was observed with mean values of (37.00), (65.50) and (94.50) days for the genotypes F81-7636-4, FB1-7636 and $H 2$, respectively. 46.93 per cent of the genotypes gave above the grand mean of grain yield.

Table 1. Range, mean, variance, broad sense heritability, genotypic and phenotypic coefficient of variation and genetic advance as per cent of mean for characters of soybean genotypes.

\begin{tabular}{|c|c|c|c|c|c|c|c|c|c|c|}
\hline Characters & Range & Mean \pm S.E Mean & $\sigma^{2} \mathrm{~g}$ & $\sigma^{2} \mathrm{e}$ & $\sigma^{2} \mathbf{p}$ & GCV (\%) & PCV (\%) & $H^{2}(\%)$ & GA & GA (\%) \\
\hline $\mathrm{DF}$ & $36.00-75.00$ & $50.06 \pm 0.95$ & 245.38 & 0.95 & 246.33 & 31.29 & 31.35 & 99.61 & 23.62 & 47.18 \\
\hline DPS & $65.00-103.00$ & $72.60 \pm 0.80$ & 82.51 & 0.58 & 83.09 & 12.51 & 12.56 & 99.30 & 13.63 & 18.77 \\
\hline $\mathrm{DM}$ & $94.00-120.00$ & $111.10 \pm 0.87$ & 135.22 & 0.76 & 135.98 & 10.47 & 10.50 & 99.44 & 16.97 & 15.28 \\
\hline PH & $20.00-62.00$ & $35.27 \pm 1.18$ & 197.7 & 1.48 & 199.18 & 39.87 & 40.02 & 99.26 & 20.62 & 58.48 \\
\hline PPP & $9.00-28.00$ & $15.98 \pm 0.91$ & 35.06 & 0.84 & 35.90 & 37.05 & 37.49 & 97.66 & 8.52 & 53.29 \\
\hline PL & $3.50-5.00$ & $4.49 \pm 0.26$ & 0.43 & 0.07 & 0.50 & 14.52 & 15.67 & 85.86 & 0.82 & 18.24 \\
\hline BY & $11.00-31.00$ & $14.12 \pm 1.33$ & 16.49 & 1.82 & 18.31 & 28.96 & 30.52 & 90.06 & 3.11 & 22.20 \\
\hline TNPP & $4.00-47.00$ & $15.37 \pm 0.99$ & 140.08 & 1.04 & 141.12 & 77.02 & 77.30 & 99.26 & 17.92 & 116.64 \\
\hline ENPP & $2.00-25.00$ & $7.79 \pm 1.07$ & 49.11 & 1.25 & 50.36 & 90.00 & 91.14 & 97.52 & 10.42 & 133.86 \\
\hline RV & $3.00-13.00$ & $4.96 \pm 0.58$ & 4.23 & 0.36 & 4.59 & 41.47 & 43.20 & 92.16 & 2.96 & 59.76 \\
\hline RDW & $3.00-5.00$ & $3.53 \pm 0.47$ & 0.38 & 0.2 & 0.58 & 17.87 & 22.08 & 65.52 & 0.29 & 8.28 \\
\hline RBR & $11.11-33.33$ & $25.50 \pm 1.93$ & 23.63 & 3.67 & 27.30 & 19.06 & 20.49 & 86.55 & 5.86 & 22.98 \\
\hline HSW & $8.00-22.00$ & $13.68 \pm 1.05$ & 13.20 & 1.17 & 14.37 & 26.55 & 27.70 & 91.86 & 5.13 & 37.48 \\
\hline GY & $444.00-2134.00$ & $885.76 \pm 30.51$ & 152972.8 & 979.09 & 153951.89 & 44.16 & 44.30 & 64.66 & 593.49 & 67.01 \\
\hline
\end{tabular}

$\mathrm{DF}=$ Days to $50 \%$ flowering, DPS=Days to $50 \%$ pod setting, $\mathrm{DM}=$ Days to maturity, $\mathrm{PlH}=\mathrm{Plant}$ height, $\mathrm{PPP}=\mathrm{Pod}$ per plant, $\mathrm{PL}=\mathrm{Pod}$ length, $\mathrm{BY}=\mathrm{Biomass}$ yield, $\mathrm{TNPP}=$ Total nodules per plant, ENPP=Effective nodules per plant, RV=Root volume, RDW= Root dry weight, RBR=Root to biomass ratio, HSW=Hundred

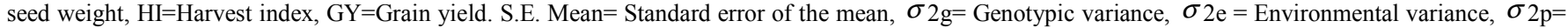
Phenotypic variance, H2 $(\%)=$ Broad sense heritability, GCV $(\%)=$ Genotypic coefficient of variation, PCV $(\%)=$ Phenotypic coefficient of variation, $(\%)$ $\mathrm{ECV}=$ Environmental coefficient of variation, $\mathrm{GA}=$ Genetic advance, $\mathrm{GA}(\%)=$ Genetic advance as per cent of mean.

Characters such as root to biomass ratio, root volume, pod length and hundred seed weight showed higher values with mean values of $25.50 \%, 4.96,4.49 \mathrm{~cm}$ and $13.68 \mathrm{~g}$, respectively. The genotypes such as $H 18$, Promoveria and $I A C-6$ scored the highest values of root to biomass ratio $(32.29 \%)$, root volume $\left(12.50 \mathrm{~cm}^{3}\right)$ and hundred seed weight $(21.50 \mathrm{~g})$, respectively. Therefore, if the breeding objective is to improve the above traits the respective genotypes should be given due attention.

\subsection{Estimates of Variance Components}

Grain yield, days to $50 \%$ flowering, pod number per plant, plant height, total nodules per plant, effective nodule per plant, harvest index, biomass yield, root volume and hundred seed weight have exhibited high genotypic and phenotypic variances. Phenotypic coefficient of variation (PCV) values ranged from $10.50 \%$ for days to maturity to $91.14 \%$ for effective nodules per plant; whereas the genotypic coefficient 
of variation (GCV) ranged from $10.47 \%$ for days to maturity to $90.00 \%$ for effective nodules per plant. High PCV and $\mathrm{GCV}$ values were recorded for grain yield, days to flowering, biomass yield, number of pods per plant, hundred seed weight, plant height, root volume, total nodules per plant, effective nodules per plant, and harvest index indicating the availability of adequate variability for these traits which aids in the improvement of the respective characters. PCV and GCV values greater than $20 \%$ are regarded as high, whereas values less than $10 \%$ are considered to be low and values between $10 \%$ and $20 \%$ to be medium. Based on this delineation, Genotypic coefficients of variation (GCV) and phenotypic coefficient of variation (PCV) values were medium for days to pod setting, days to maturity and pod length. Medium GCV values were recorded for days to pod setting, days to maturity and pod length. High PCV values were recorded for root dry weight and root to biomass ratio.

\subsection{Estimation of Broad-Sense Heritability and Genetic Advance}

Root dry weight and days to $50 \%$ flowering had moderate and high heritability with $65.52 \%$ and $99.61 \%$ respectively.

All characters except root dry weight and grain yield, $65 \%$ and $64.66 \%$ respectively, had very high heritability. This indicates that selection will be the best approach to be employed to identify the best soybean genotypes for the traits with high heritability. This is because; there will be a close correspondence between the genotype and the phenotype of the genotypes, due to the relative small contribution of the environment to the phenotype. But, for characters with low heritability, selection may be considerably difficult or virtually impractical, due to the masking effect of the environment. The magnitudes of heritability for most of the quantitative characters were moderate to high.

Genetic advance as percent of mean ranged from 8.28 for root dry weight to 133.86 for effective nodules per plant (Table 1). Within this range, a relatively high genetic advance was observed for effective nodules per plant (133.86\%), total number of nodules per plant $(116.64 \%)$, harvest index (72.74\%), grain yield $(67.01 \%)$, root volume $(59.76 \%)$, plant height (58.48) and days to $50 \%$ flowering (47.58). Low genetic advance as per cent of mean values were observed for root dry weight (8.28), days to maturity (15.28), pod length (18.24\%) and days to pod setting (18.77\%). This low estimate of genetic advance as a percent of mean arises from low estimate of phenotypic variance and heritability.

The present study showed high heritability coupled with high expected genetic advance as per cent of mean for effective nodules per plant, total nodules per plant, pod number per plant and harvest index across both locations.

\subsection{Cluster Analysis}

Divergence analysis was used to categorize genotypes that are similar into one group and others into a different group. D-square statistics $\left(\mathrm{D}^{2}\right)$ developed by Mahalanobis (1936), has been used to classify the divergent genotypes into different groups [15].

The genotypes were classified into three clusters (Table 2). Cluster II was the largest cluster with 29 (59.18\%) genotypes followed by cluster I which contained 19 genotypes or almost $38.77 \%$ of the total population. Cluster III contained only 1 genotype which is $2.04 \%$ of the total population.

Table 2. The distribution of genotypes into three clusters based on $D^{2}$ analysis for the 49 soybean genotypes.

\begin{tabular}{lll}
\hline Cluster & Number of genotypes & Genotypes included \\
\hline \multirow{2}{*}{ I } & \multirow{2}{*}{19} & H10, G00386, Promoveria, IAC-11, H4, Essex, H1, Crowford, PR-41(339), G01892, G00141, AGS-3-1, H14, \\
& & PR-160-6, G01853, PR-143 (14), F82-7629-2, Clark-63k, V1-1 \\
& \multirow{2}{*}{ II } & AGS-234, AGS-214, HS-82-2136, SR-4-1, H18, PR-149-81-EP7, Davis, FB1-7636, TGX-1895-49-F, G03705, \\
& \multirow{2}{*}{ III } & AGS-299-2, H2, H3, H5, TGX-297-6E-1, PR-145-2, JSL-1, G9945, F81-7636-4, Lotus, SR-4-3, Protana, IAC-6, \\
\end{tabular}

Table 3. Cluster mean for 14 characters in soybean genotypes.

\begin{tabular}{llll}
\hline Traits & Cluster I & Cluster II & Cluster III \\
\hline Days to 50\% flowering & $48.60^{*}$ & 50.48 & $65.50^{* *}$ \\
Days to 50\% pod setting & $71.52^{*}$ & 73.27 & $73.50^{* *}$ \\
Days to maturity & 114.21 & $108.87^{*}$ & $116.50^{* *}$ \\
Plant height & $33.18^{*}$ & 35.72 & $61.50^{* *}$ \\
Pod number per plant & $14.02^{*}$ & $17.27^{* *}$ & 15.50 \\
Pod length & $4.56^{* *}$ & 4.45 & $4.00^{*}$ \\
Biomass yield & $13.42^{*}$ & 14.06 & $24.00^{* *}$ \\
Total nodules per plant & 15.65 & $14.68^{*}$ & $29.50^{* *}$ \\
Effective nodules per plant & 8.44 & $7.24^{*}$ & $11.00^{* *}$ \\
Root volume & 5.00 & $4.81^{*}$ & $8.50^{* *}$ \\
Root dry weight & $3.42^{*}$ & 3.43 & $4.50^{* *}$ \\
Root to biomass ratio & $26.14^{* *}$ & 25.42 & $15.71^{*}$ \\
Hundred seed weight & $12.92^{*}$ & 13.98 & $19.50^{* *}$ \\
Harvest index & 28.06 & $36.42^{* *}$ & $17.50^{*}$ \\
Grain yield & $630.78^{*}$ & 1009.67 & $2130.00^{* *}$ \\
\hline
\end{tabular}

$* *=$ highest value and $*=$ lowest value. 


\subsection{Genetic Distance Between Clusters}

The pair wise generalized squared distance $\left(D^{2}\right)$ among clusters is depicted in table 2 . The $\chi^{2}$-test for the three clusters (Table 4) indicated that there was statistically significant difference among the clusters except cluster I and III (11.85). The highest cluster distance was recorded between cluster I and cluster III $\left(\mathrm{D}^{2}=304.36\right)$ followed by cluster I and cluster III $\left(D^{2}=224.41\right)$, which revealed that these clusters were genetically more divergent from each other.

Crosses involving parents belonging to most divergent clusters are expected to manifest maximum genetic recombination and variation in genetic architecture.

In most of the cases, genotypes collected from same place of origin fell in to the different clusters and from different places of origin fell in to same cluster. Regarding to genotypes collected from Ethiopia, genotypes from Awassa area are distributed in cluster I $(27.77 \%)$ and in cluster II $(72.23 \%)$. Genotypes from Pawe area are distributed in to the three clusters $60 \%$ in cluster II, $30 \%$ in cluster I and the rest $10 \%$ in cluster III. The genotypes from Jimma area are distributed in cluster I (66.66\%) and in cluster II (33.34\%). The genotype from Assosa area is found in cluster II.

In this study the results showed that there was moderate diversity in soybean genotypes. However, there was no definite relationship between geographic diversity and genetic diversity. It is suggested that selection of parents for hybridization need not necessarily be based on geographic diversity but genetic diversity must form the base for parental selection.

Table 4. Mahalanobis distance between groups of soybean genotypes.

\begin{tabular}{llll}
\hline CLUSTERS & I & II & III \\
\hline I & - & $11.85^{\text {ns }}$ & $304.36^{* *}$ \\
II & & - & $224.41^{* *}$ \\
III & & - \\
\hline
\end{tabular}

$\chi^{2}=23.68$ and 29.14 at $5 \%, 1 \%$ probability level respectively.

\section{Conclusion}

Based on the relative squared distance values $\left(\mathrm{D}^{2}\right)$ between any two genotypes, the 49 soybean genotypes were grouped into three distinct clusters. This indicates that the soybean genotypes were moderately divergent.

The study generally implied the presence of moderate genetic variability among the tested genotypes. Thus, there is an opportunity to bring about improvement through direct selection or hybridization.

The principal component analysis indicated five principal components (PCs) having eigenvalues between 1.08 and 4.27 explained a cumulative of $73.81 \%$ of the total variation among the genotypes. It was also noted that differentiation of the genotypes into different cluster was because of a cumulative effect of a number of characters rather than the small contribution of each character.

Phenotypic coefficient of variability (PCV) values ranged from $10.50 \%$ for days to maturity to $91.14 \%$ for effective nodules per plant, whereas the genotypic coefficient of variability (GVC) ranged from $10.47 \%$ for days to maturity to $90.00 \%$ for effective nodules per plant. The traits such as, grain yield, days to $50 \%$ flowering, biomass yield, number of pods per plant, hundred seed weight, plant height, root volume, total nodules per plant, effective nodules per plant, and harvest index had high phenotypic (PCV) and genotypic coefficient of variability $(\mathrm{GCV})$ values.

High heritability coupled with high expected genetic advance was observed for effective nodules per plant, total nodules per plant, harvest index, pod number per plant, biomass yield, plant height and root volume. Thus, these characters can be improved through selection more easily than other characters.

In this study high phenotypic coefficient of variation, genotypic coefficient of variation, heritability and genetic advance as per cent of mean was recorded for effective nodules per plant, total nodules per plant, harvest index, pod number per plant and plant height.

\section{References}

[1] Agdew Bekele and Getnet Alemahu (2005). Desirable traits influencing grain yield in soybean (Glycinemax(L.)Merrill) Int. Inst. Sci. Tech. Edu. 2: 3-6.

[2] Ajayi AT, Adekola MO, Taiwo BH, Azuh VO (2014) Character expression and differences in yield potential of ten genotypes of cowpea (VignaunguiculataL.). Plant. 4: 63-71.

[3] Arashad M., Ali N., and Ghafoor, A., (2006) Character correlation and path coefficient in soybean Glycine max (L.) Merrill. Pak. J. Bot. (2006) 38(1): 121-130.

[4] Asrat A.; Abush T.; Sentayehu A. and Mulugeta A. Food and Forage Legumes of Ethiopia: Progress and Prospects. Proceedings of the Workshop on Food and forage Legumes, 22 26 September 2003. Addis Ababa, Ethiopia.

[5] Atanf M, Tesfaye K, Kifle D (2015a) The importance of legumes in the Ethiopian farming system and overall Economy: an overview. Am J Exp Agric.7:347-358.

[6] Atnaf M, Tesfaye K, Dagne K, Wegary D (2015b) Extent and pattern of genetic diversity in Ethiopian white lupin landraces for agronomical and phenological traits. Afr Crop Sci J. 23: 327 341.

[7] Babar, M. A , Newaz, M. A and Jahan, M. A. (2002). Identification of selection parameters for yield improvement in French bean. Bangladesh Jour. Agric. Sci. 29: 85-89.

[8] Getnet B., Alamerew S., Tesfaye A., Barnabas J., Character Correlation and Path Analysis for Yield and Yield related Components in Soybean (Glycine max L.) Genotypes (2016). International Journal of Sciences \& Applied Research. IJSAR, 3(12), 2016; 97-104.

[9] Getnet B., Alamerew S., Tesfaye A., Barnabas J., Correlation and Path Analysis for Yield and Yield related Components in Soybean (Glycine max L.) Genotypes (2016). International Journal of Sciences \& Applied Research. IJSAR,3(12), 2016; 105-112. 
[10] Janaki M Naidu LN, Ramana CV and Rao MP (2015) Assessment of genetic variability, heritability and genetic advance for quantitative traits in chilli (Capsicum annuumL.). The Bioscan 10(2): 729-733.

[11] Patil AS, Punewar AA, Nandanwar HR, and Shah KP (2014) Estimation of variability parameters for yield and its component traits in groundnut (ArachishypogaeaL.). The Bioscan 9(2): 749-754.

[12] Kumara PS Sanjeev BG and Ravana PV (2015) Studies on correlation and path analysis for traits related to water use efficiency and pod yield and its component in groundnut (Arachishypogaea L.). The Bioscan 10(4):2155-2158.

[13] Kang, Y. J.; Kim, S. K.; Kim, M. Y.; Lestari, P.; Kim, K. H.; Ha, B.-K.; Jun, T. H.; Hwang, W. J.; Lee, T.; Lee, J. Genome sequence of mungbean and insights into evolution within Vigna species. Nat. Commun. 2014, 5, 5443.

[14] Kim, S. K.; Nair, R. M.; Lee, J.; Lee, S.-H. Genomic resources in mungbean for future breeding programs. Front. Plant Sci. $2015,6,626$.

[15] Mahalanobis, P. C., (1936). On the generalized distance in statistics. In : Proceedings of National Academy of Science (Indian), $2:$ 49-55.

[16] Malek MA, Rafii MY, Shahida S, Afroz M, et al. (2014) Morphological characterization and assessment of genetic variability, character association, and divergence in soybean mutants. Sci World J.
[17] Payasi DK (2015) Genetic variability analysis for seed yield and its components in mungbean (VignaradiataL. Wilczek). Int J Plant Breed Genet. 9: 177-188.

[18] Poehlman, J. M. and D. A. Sleper, (1995). Breeding Field Crops. 4th ed. Iowa State University Press, Ames, Iowa 50014, USA.

[19] Salmeron, M., L. C. Purcell, L. Earnest, and J. Ross. 2015a. Soybean yield response: planting date and maturity groups in Arkansas.

http://www.midsouthsoybeans.com/52618_32_AR_Maturity Guide_10_21_15.pdf.

[20] Salmeron, M., L. C. Purcell, L. Earnest, and J. Ross. 2015b. Soybean yield response: planting date and maturity groups in Tennessee.

http://www.midsouthsoybeans.com/54407 29 TN_MaturityG uide_LR.PDF.

[21] Salmeron, M., L. C. Purcell, L. Earnest, and J. Ross. 2015c. Soybean yield response: planting date and maturity groups in Missouri.

http://www.midsouthsoybeans.com/54407_MO_Maturity_Gui de_FINAL.PDF.

[22] SAS Institute Inc., 2001. Statistical Analysis System, Version 9.2. Cary, North Carolina, USA. 